\title{
LITERATURE
}

๙

\section{Subhradeep Chatterjee}

JADAVPUR University, KolKata, India SUBHRA1996@GMAIL.COM

\section{"Kubla Khan" and Islamic Architecture: Retracing Symbolism and Investigating Imagination}

\begin{abstract}
Samuel Taylor Coleridge's poem "Kubla Khan" draws upon the historical Xanadu, the summer palace of the Mongol ruler, Kubla Khan, and presents an architectural space that uses a commixture of imagination and mimesis to present a space of historical and supernatural transactions and transcends geographical limits.

The architectural characteristics of Kubla Khan's pleasure-dome in Xanadu are replete with similarities with various elements of Islamic architecture. The walled-in structure bears a great deal of resemblance to the layout of Islamic paradise gardens which are often found in the chaharbagh structure in mosques and Islamic sites. Furthermore, the poem proposes a setting which has marked similarities with Kashmir and its geographical spaces.

In this paper, I have aimed to present a coherent sequence of arguments in an attempt to relate the similarity of Xanadu with real geographical spaces and its intersection with elements of Islamic architecture through an examination of its actual history along with the various tales of Xanadu found in the accounts of Marco Polo and other travellers. The paper also compares Xanadu with the structural compositions of the Taj Mahal in India and later, the Mecca, and also engages in discussing its allegorical significance in relation with the Islamic paradise or Jannah.

The paper also discusses the possible sources for Coleridge's poem and how they might have influenced him and his dreams and investigates the poem's role in revisiting the fabled summer city of the Mongol ruler and its pleasure-dome configuration that resembled his paradise.
\end{abstract}

Keywords: Kubla Khan; Samuel Taylor Coleridge; Islamic architecture; paradise garden; Taj Mahal; Mecca; Xanadu; Kashmir 
The literary epoch of Romanticism foregrounded imagination as one of its key elements. With its preceptial focus on revisiting of the past and the connection with nature, Romantic literature drew upon imagination as a mode of memory and projection (Coleridge 1996, 749). Samuel Taylor Coleridge's poem "Kubla Khan. Or, a vision in a dream. A Fragment" attempts such a revisitation of memory (in the form of a dream) and presents to the readers the pleasure-dome of the Mongol ruler, Kubla Khan, with its resplendent architecture and the elements of nature that come together to form a supernatural world of prophecies and sacred beginnings.

The origin of the poem is attributed to Coleridge's opium-induced dream after reading Purchas's Pilgrimes in which there is a description of Kubla Khan's summer capital of Xanadu. The dream was broken by the arrival of a person from Porlock on business, thus making the poem a fragment. Coleridge wrote the poem from what he remembered from the dream.

The text describes the stately pleasure-dome of the Mongol ruler Kubla Khan in Xanadu and the nature surrounding it. The lyrical I writes about "A sunny pleasure-dome with caves of ice!," suggesting an enchanted setting improbable in the geographical space that is described. After the description of the wild surroundings of Xanadu, our attention is shifted onto Kubla Khan who hears ancestral voices prophesying war. In the concluding lines of the poem, the speaker reminisces about a vision he once had - of a woman playing a dulcimer and of the sunny dome he will build.

In this paper, I aim to explore Xanadu's architecture and the pleasure-dome that the poem visualizes and compare them with major Islamic structures, while referring to the various theories about the textual pleasure-dome proposed by several scholars.

The pleasure-dome of Kubla Khan presents a scene of improbability - of measureless caverns and the river, juxtaposed with sunny domes and caves of ice, a miracle that accentuates the grand and magical essence of the place. Xanadu is described as a land of sinuous streams that flow amid gardens and forests. Its exterior is savage and contrasts sharply with the holy summer capital: it is depicted as a space of great turmoil and deep chasms through which the sacred river Alph flows before coming to a sunless sea. The violent characteristics of its path are counterpoised with the calm nature of the "lifeless ocean" which marks the end of its journey.

Commenting on the pleasure-dome, John Beer visualizes it as the "lost paradise" which is ultimately regained by the end of the poem, writing about the dome as a miracle where the caves of ice and the sunny spots co-exist in harmony. As he observes in Coleridge the Visionary: "[it] is a poem with two major themes: genius and the lost paradise. In the first stanza the man of commanding genius, the fallen but daemonic man, strives to rebuild the lost paradise in a world which is, like himself, fallen" (Beer 2017, 248).

The image of the dome is depicted here as a creation of Kubla Khan on his journey towards regaining paradise. The setting and the creation of the dome as his site of power positions him as ruling his realm from a "sacred" space with the architecture and the passage of the river resembling a holy structure of worship similar to mosques and Islamic 
"Kubla Khan" and Islamic Architecture: Retracing Symbolism and Investigating... 69

paradise gardens. In John Beer's reading, the pleasure-dome functions as the thesis and the wild atmosphere of the journey of the river as the antithesis which contradicts the holy and calm nature of the summer palace. Additionally, the ancestral voices prophesying war communicate the knowledge of the future to the ruler (Beer 2007, 248).

This idea of a paradise as visualized in the poem by the critic (Beer 2007, 248) is essentially the Biblical Paradise, that is, the Garden of Eden. However, it may arguably be read also as the Islamic Paradise - Jannah — which is depicted in the Qur'an as a place of fountains and joy and gardens with rivers flowing through it (Qur'an, Surah 9, Ayah 72) (Dawood 1991).

The Venetian traveller Marco Polo wrote about Xanadu (which he allegedly visited in 1275) as a palace surrounded by a "park", featuring many rivers and fountains, beautiful meadows and wild animals (Polo). The walled park, decorated with gilt dragons, is the place which Kubla Khan surveys, accompanied by his leopard (Polo). Based on Marco Polo's description of Xanadu, Samuel Purchas wrote about the Marble Palace of Kubla Khan, the gilt dragons, the meadows and streams in the park where he roamed with his leopards (Chayes 1966, 8).

Interestingly, Kubla Khan's pleasure dome in Xanadu bears some resemblance to the architecture of Islamic paradise gardens whose standard features are canals, pools, and fountains. In his article "Rethinking the Islamic Garden," Attilio Petruccioli writes about the architecture of Mughal royal cities:

The royal city is based on three recurrent key themes: first, gardens and palaces, merged together as places of heterodox pleasure; second, the importance of the court ceremonial; and third, the vast and complex system of gardens and palaces, sometimes taking the form of a labyrinth as if to express the idea of the king's divine and quasi-magical isolation $(1998,6)$.

The royal city of Xanadu has the first of the characteristics mentioned above. Petruccioli further writes:

In fact, besides the function of retreat from reality and protection from wild nature, the Islamic garden has generally aimed to represent, in more or less explicit form, the religious paradise. To complicate the play on imagery and metaphor, it also offers an allegorical sequence for the exaltation of royal power. (Petruccioli 1998, 6)

This idea of the Islamic gardens resembling a religious paradise resonates well with John Beer's comments on "Kubla Khan" where he visualizes the pleasure-dome as a paradise that the Mongol emperor has decided to regain. The allegorical nature of the gardens as symbolizing royal power is also well founded in Coleridge's poem where the great Mongol emperor is depicted as a mighty king who rests in his summer capital and from there reigns over his dominions.

The dome as the centre of power and control and the surrounding city as the realm with the lands beyond is discernible in the descriptions of Xanadu in both literature 
and history (Chayes 1966, 8). The panopticon-like structure of the centre of control is also perceptible in the very architecture of the dome. The geometric quartered pattern of Persian gardens consists of the rectangular space, often intersected by streams and pathways (Farahani, Motamed and Jamei 2016, 3). The river Alph flowing through the geographical space of Xanadu is not unlike this model.

Furthermore, the "introverted" nature of the Persian garden structure is evident in the characteristics of the walled enclosure. The calm and privacy of the main centre is thus ensured in the paradise through introversion (Farahani, Motamed and Jamei 2016, 8). The geometrical alignment of the components of the Persian gardens along with the river element is well explained by Farahani, Motamed and Jamei:

Based on Henry Corbin's study on the Mazdean cosmology, Alemi argues that Persian chahar-bagh is a symbol of the universe, including the elements that can be found in a Persian chahar-bagh (Alemi 1390). In chahar-baghs, terraces symbolize the cosmic mountains and the creation of the edifice or throne at the highest level represents the position of the God. A great pool is placed in front of the edifice representing the cosmic ocean as the source of all waters which can irrigate the whole garden. (Farahani, Motamed and Jamei 2016, 12)

The throne of Kubla Khan and the arrangement of the dome, along with the river Alph ending in the "lifeless ocean" after its tumultuous journey, bears some similarity to the description above. The river Alph symbolizes the beginning of matter and life as the word is possibly derived from the first letter of the Arabic alphabet, Aleph. At the same time, the phonetic closeness to the first Urdu letter, Alif, or the first Greek letter, Alpha, also cannot be ignored. Overall, the very essence of its meaning as the "beginning" suggests a symbolic association of creation with Xanadu. While the "lifeless ocean" seems to create a sense of gloom in signifying death, the Aleph again resuscitates the life and symbolizes the beginning (Coleridge 1997, 28).

The Persian garden layout is a common feature of most Islamic structures and its elements can be found, for instance, in the Taj Mahal, in India, where the mausoleum along with the river Yamuna at the front is reminiscent of the Persian garden structure with a "caharbagh" (Koch 2005, 4). More importantly, a very similar layout is discernible in Kubla Khan's pleasure-dome. The dome-in-a-square-space structure of Taj Mahal along with the river Yamuna provides a scene of strong similarity to the pleasure-dome with its boundary wall and the river Alph flowing from it.

John Livingstone Lowes, writing about the Dal Lake in Kashmir, observes:

There, without question - together with that "great and vast dome of white marble" which Bernier saw with delight surmounting Shah Jehan's Taj-Mahal at Agra-are elements which might have risen up, blended and transfigured, in the lovely image of the dream. (Lowes 1957, 353). 
"Kubla Khan" and Islamic Architecture: Retracing Symbolism and Investigating... 71

The river Yamuna flows into the sacred river of the Hindus - the Ganges - and the journey of it from the Taj Mahal resonates with the symbolism of the sacred river Alph.

Another example of a Xanadu-like structure would be the holy site of Islamic pilgrimage-Mecca, or rather, the Great Mosque of Mecca (Masjid al-Haram with the Ka'bah (al-Ka'bah) (literally "the cube") at the centre of the walled structure of the Mosque. Considered as the "House of God", the Ka'bah is the centrepiece of worship and reverence for the followers of Islam (Majid 1926, 276).

There is a similarity in the centre of focus and the fact that the structure is walledin. The Mecca presents a cubical centrepiece with the surrounding walls akin to a circular shape, the arrangement which is reversed in the pleasure-dome where we have a spherical dome in the centre of the palace gardens. Though a loose comparison, the resemblance cannot be totally ignored - particularly with regard to the Ka'bah and the Marble Palace of Kubla Khan both being the sites of power/worship, ones that emanate absoluteness.

Garland H. Cannon, writing about Coleridge's work, draws parallels with the poem "A Hymn To Ganga" by an Oriental scholar William Jones while pointing to the similarity in the descriptions of the tumultuous journey of the rivers Ganges and Alph in the poems (Cannon 1955, 2). In fact, there has always been a contention in associating "Kubla Khan" with the Indian influence as elements in the description of Xanadu have been, at times, compared with Kashmir. Commenting on "Kubla Khan" and the Kashmir link, John Livingstone Lowes (in The Road To Xanadu) quotes François Bernier's accounts:

Returning from Send-brary I turn'd a little aside from the road to go and lie at Achiavel, which is an house of pleasure of the ancient kings of Kachemire, and at present of the great Mogol [...] That which most adorns it is a fountain [...] It breaks out of the earth, as if by some violence it ascended up from the bottom of a well, and that with such an abundance as might make it to be called a river rather than a fountain [...] $(1957,353)$.

The resemblance between this description and the depiction of the seething fountain in the poem is quite vivid: "And from this chasm, with ceaseless turmoil seething, / As if this earth in fast thick pants were breathing, / A mighty fountain momently was forced" (Coleridge 1997, 17).

In Gardens of the Great Mughals we find the following description of Shalimar Bagh in Kashmir:

A canal, about a mile in length and twelve yards broad, runs through the marshy swamps, the willow groves, and the rice-fields that fringe the lower end of the lake, connecting the garden with the deep open water. (Villiers-Stuart 1913, 162).

It is interesting to note that the journey of the river of "Kubla Khan" to the "lifeless ocean" entails a similar passage through cedarn covers, greenery and "savage" places. Therefore, the Dal Lake can be seen as an alternate vision of the ocean in this context. 
"Kubla Khan," with its enchanting images and spaces transcends realistic depictions and combines elements of myths and the supernatural through imagination as a mode of projection and memory, intersecting with the Romantic ideal that Nature will always overcome transient human creations. Some elements of the poem are supposed to be influenced by Coleridge's reading of Purchas's Pilgrimes, along with other works such as William Jones' poem "A Hymn to Ganga" (Cannon 1955, 139). Therefore, the assertion that the imagery of the text is linked to descriptions of various structures and places cannot be ignored. The setting of the pleasure-dome is based on the descriptions of the summer capital of the real Kubla Khan, the great Mongol emperor, therefore, the influences of Islamic architecture in the description of his summer capital are quite possible.

Further, the tendency of Orientalism in portraying the East and its elements as the "exotic" is reflected to a certain degree in Coleridge's treatment of the Eastern elements, such as the Indian setting of the Ganges and the Mongol ruler, with both being exoticized to produce a sense of awe. The Islamic elements have had an important role and position in the perception of the East by the colonizers (and by extension, the British Romantics) which often resulted in their attempts at portraying them as the unknown and hence, interesting (and exotic). Jones' poem and the tale of Kubla Khan perhaps had had such an effect on Coleridge which led him to compose the lines which rely on supernatural imageries for its desired effect. The poem's presentation of scenes which evoke the sense of wonder are linked to the understanding of Orientalism as the mystical Other. This, in turn, shows how the Eastern and hence the "Oriental" elements became interpolated into the poetic narrative of the said British text as a microcosmic projection of Coleridge's imagination and perhaps the Romantic imagination as well.

The architectural syncretism of the pleasure-dome of "Kubla Khan" elicits a re-reading of the poem implying not only a presentation of the summer capital as indebted to major world cultures, but also suggesting an explanation for the poem's structure, where prophecies, elements of wild nature in the description, and a number of architectural influences can be justified within the larger metanarrative of the poet's broken dream that shaped the poem.

\section{References}

Beer, John. Coleridge the Visionary. Humanities Ebooks, 2007. PDF.

Cannon, Garland H. “A New, Probable Source for 'Kubla Khan.” College English 17, no. 3 (1955): 136. doi:10.2307/495734.

Chayes, Irene H. "'Kubla Khan" and the Creative Process." Studies in Romanticism 6, no. 1 (Autumn 1966): 1-21. http://www.jstor.org/stable/25599673.

Coleridge, Samuel Taylor. "Kubla Khan. Or, a Vision in a Dream. A Fragment." In The Complete Poems of Samuel Taylor Coleridge. London: Penguin, 1997.

Coleridge, Samuel Taylor. 1996. "Imagination.” In Biographia Literaria, edited by Anne K Mellor and Richard E Matlak, 749-50. London: Harcourt Brace College Publishers. 
Pobrane z czasopisma New Horizons in English Studies http://newhorizons.umcs.pl Data: 26/04/2023 14:06:27

"Kubla Khan" and Islamic Architecture: Retracing Symbolism and Investigating... 73

Dawood, N. J. The Koran. New York: Penguin Books, 1991.

Farahani, Leila Mahmoudi, Bahareh Motamed, and Elmira Jamei. "Persian Gardens: Meanings, Symbolism, and Design." Landscape Online, 2016, 1-19. doi:10.3097/lo.201646.

Koch, Ebba. "The Taj Mahal: Architecture, Symbolism, And Urban Significance.” Muqarnas Online 22, no. 1 (2005): 128-49. doi:10.1163/22118993-90000087.

Lowes, John Livingstone. The Road to Xanadu: A Study in the Ways of the Imagination. Princeton University Press, 1957.

Majid, Haji Abdul. “A Malay's Pilgrimage to Mecca." Journal of the Malayan Branch of the Royal Asiatic Society 4, no. 2 (1926): 269-87. JSTOR.

Petruccioli, Attilio. "Rethinking the Islamic Garden." In Transformation of Middle Eastern Natural Environment: Legacies and Lessons, edited by Jane Coppock and Joseph A. Miller, 349-63. New Haven: Yale University Press, 1998.

Polo, Marco. "Of the City of Chandu, and the Kaan's Palace There." In The Travels of Marco Polo, translated by Henry Yule. Wikisource.

Said, Edward W. Orientalism. New York: Pantheon Books, 1978.

Villiers-Stuart, C. M. Gardens of the Great Mughals. Adam and Charles Black, 1913. 